Available for free online at https://ojs.hh.se/

IฯSTB

Journal of Intelligence Studies in Business 1 (2011) 29-39

\title{
Methodology of Integration for Competitive Technical Intelligence with Blue Ocean Strategy: Application to an exotic fruit
}

\author{
Marisela Rodríguez Salvador* and Manuel Alejandro Bautista Reyes** \\ *Instituto Tecnológico y de Estudios Superiores de Monterrey (ITESM) Campus Monterrey, \\ Eugenio Garza Sada 2501, Monterrey, Mexico \\ marisrod@itesm.mx \\ **Exa-Tec Campus Monterrey \\ reyestec@gmail.com
}

Received 10 March 2011; received in revised form 22 November 2011; accepted 28 December 2011

\begin{abstract}
This article presents a new methodology that integrates Competitive Technical Intelligence with Blue Ocean Strategy. We explore new business niches taking advantage of the synergy that both areas offer, developing a model based on cyclic interactions through a process developed in two stages: Understanding opportunity that arise from idea formulation to decision making and strategic development. The validity of our approach (first stage) was observed in the evaluation of an exotic fruit, Anacardium Occidentale, in the South of the State of Veracruz, Mexico with the support of the university ITESM, Campus Monterrey. We identified critical factors for success, opportunities and threats. Results confirm the attractiveness of this crop.
\end{abstract}

Keywords: Competitive Technical Intelligence, Blue Ocean Strategy, Anacardium Occidentale

\section{Introduction}

With an area of $1,964,375 \mathrm{~km}^{2}$, Mexico is a country located in the southern part of North America, with a varied territorial geography: arid, mountainous, coastal and desert. Its population is approximately 112,336,538 inhabitants (INEGI 2010) and its economy is based substantially on the traditional industry, high-tech industry, and agriculture (CIA 2011).
In Mexico, one of the main industrial areas is located in the northern part of the country, in Monterrey, Nuevo Leon. In this city the main campus of the Instituto Tecnológico y de Estudios Superiores de Monterrey (ITESM) is located, which is one of the most important private academic institutions in Latin America. The Institute has since its beginning developed strong relations with the industry resulting 
in broad training and consulting services (Noriega and Rodríguez 2010, ITESM 2011).

Since 2001 a unit of Competitive Technical Intelligence is established on the Monterrey Campus headquarters (Center of Quality and Manufacturing). Its purpose is to promote academic and research activities within this field and assist companies in the identification of opportunities and drawbacks for improvement in innovation processes (Noriega and Rodríguez 2010, 30-39).

In 2010, a Master degree student in the Quality and Manufacturing program asked for support in developing his Master's thesis with a project to evaluate the potential niche of an agricultural product from the southern part of Mexico. The purpose was to develop a model to evaluate the feasibility of production of an exotic fruit, applying both methodologies: Competitive Technical Intelligence and Blue Ocean Strategy. The final aim was to help improve the competitiveness of a group of farmers of the Olmeca Region in Veracruz.

\section{Competitive Technical Intelligence and Blue Ocean Strategy}

The Competitive Intelligence field in the Anglo Saxon world has its origins around the 1600's in England when Sir Francis Bacon recognized that scientific knowledge is the engine that generates technological change and environmental evolution. The importance of collection and assimilation of sources of technological information was established in the 1800's, as industries of textile, steel and others evolved. However, it wasn't until the 1900's that the field of Competitive Intelligence was recognized as a profession (Ashton and Klavans 1997). In 1986 the Society of Competitive Intelligence Professionals (SCIP) was established in the USA. SCIP is a nonprofit global organization whose purpose it is to promote the field and develop professional knowledge in order for organizations to be more competitive.

Competitive Intelligence refers to a systematic and ethical process for collecting, analyzing and managing external information that could have an impact on the plans, decisions and operations of a company. It is an analytical process that transforms disperses data from competitors, industry and market to apply knowledge in strategic areas related to capabilities, intentions, performance, and position of competitors (SCIP 2011). Whereas the term 'competitive intelligence' refers to the process that involves the handling of general information about the external competitive atmosphere of the business, competitive technical intelligence (CTI) is also concerned with the associated scientific and technological events of research, development and innovation processes; technological acquisition policies, joint venture, portfolios of $\mathrm{R} \& \mathrm{D}$, etc. (Escorsa and Rodriguez 1997, 835).

Competitive Technical Intelligence pursues three main objectives:

1. Timely awareness of technological events that could improve or harm the organization's performance.

2. Identification of new products/processes, and collaboration prospects to create or improve business.

3. Comprehension of scientific and technological events or trends related to the competitive environment, which identifies innovative opportunities (Porter 1991).

The primary role of CTI is anticipation (early warning), a key factor in the business world today. Companies that apply this methodology successfully can hope to make decisions with more certainty and can stay ahead of future changes in the environment (Comai and Tena 2006, 113-136).

Competitive Technical Intelligence Systems have been a decisive factor of success for companies like: L'Oreal, Master Lock, Nestlé, American Airlines, Oracle, Hasbro, 3M, Hacer, Kellog Co. North America, Nutra Sweet, Procter \& Gamble, Johnson \& Johnson, Hewlet Packard, Southern Bell, Texas Instruments, Ford Motor Credit and Rockwell Automative Design.

Increased sales are one of the most important benefits that an organization can achieve. A study realized by Price Waterhouse Coopers in 2002 concluded that companies considering awareness of environmental changes had a sales growth of $14.2 \%$, against $11.8 \%$ from those who didn't (SCIP 2009).

From the mid-1990s there has been a substantial increase in research, literature, symposia, training and consulting in CTI and related areas.

In first world countries the value of CTI activities are well recognized for growth and competitiveness (Grisaleña and Unai 2008, 26-31). In developing countries, like in Latin America, there is still much to be done in this area (Price 2000).

CTI provides a methodology interesting to Latin American organizations, in particular when they can obtain support from academic institutions that can guide them in this process, taking advantage of resources available in the institution. As Chan and Mauborgne (2004a, 8) established, there has been an accelerated commoditization of products and 
services, increased price wars, and shrinking profit margins around the world the last years. This is the more similar, and as they become more similar people increasingly make selections based on price. In overcrowded industries, differentiating brands becomes a harder strategy to implement in both economic upturns and downturns. This is why strategies that focus on the prospect of entering into an untargeted market and attracting a wider array of customers, who are not currently the target of heavy competition from other competing brands, are needed. One answer to this problem can be a Blue Ocean Strategy deployment, creating and capturing new demand with the aim of adding value in businesses not seen or thought of before. The idea of Blue Ocean Strategy was the result of a decade-long study of 150 strategic moves spanning over more than 30 industries and 100 years (1880-2000) (BOS 2011). The name Blue Ocean derives comes from the idea of imagining the market universe formed by two types of oceans: a Red Ocean and a Blue Ocean. A Red Ocean refers to a market that is already known (competition is heavy, companies are already established). A Red Ocean means staying in a competitive environment where demand of products and services has defined boundaries and the competence are known by the companies involved. A Blue Ocean refers to a market space that hasn't yet been explored and that could constitute a business opportunity. The Blue Ocean shape is set to overcome competitors and gain greater market shares (Chan and Mauborgne, 2005).

The purpose of a Blue Ocean Strategy is restructuring current market boundaries or creating an entirely new market, where competition rules are not yet set and high profits could be obtained. In this kind of scenario, competence is more or less irrelevant at the moment due to the fact that competition does not exist. Products and service standardization is low and business growth is promising (Chan and Mauborgne 2005). A Blue Ocean Strategy enables the opening of new markets, discovering new demands and consequently achieving economic benefits that allow a clear differentiation from competitors. As Chan and Mauborgne (2004b, 101-116) note, the strategy comes up from the result of limit expansion of the existent industries, applying a different logic strategy result of increased global competition. For major product and service categories, brands are becoming called "Value Innovation ". Value Innovation is the cornerstone of Blue Ocean Strategy due to the fact that it requires simultaneous pursuit of differentiation and low cost. It is a new way of thinking, an execution of a strategy to set aside the competition and break the tradeoff between value and cost.

Value could be achieved by eliminating or reducing the variables on which a company competes. The value for clients increases by searching for and creating elements that companies have not offered before.

Chan and Mauborgne, (2005) note that the real challenge is not only to be compared with competitors offering more for less; this kind of strategy could increase sales for a period, but will hardly lead to the opening of a new market. Conversely, they suggest a redirection of the strategy, where alternative products are considered focusing directly on the customer, not only on the competitors. The final objective is to build strong barriers against imitation through innovation.

Some of the companies that have successfully implemented the Blue Ocean Strategy include Cirque du Soleil, Casella Wines (Australian Wines), Netjets (Airlines), Curves (a Texan company specialized in women exercise programs), Novo Nordisk (a Danish Company that produces insulin among other products), NABI (Hungarian bus company), CEMEX, Starbucks, Dell, and The Home Depot. These companies have obtained interesting competitive advantages generating a value differentiation by offering differentiated products/services, establishing high barriers against imitation (Druehl and Schmidt 2008, 44-60).

In this context, we suggest that a systematic monitoring of the environment through Competitive Technical Intelligence can lead to knowledge of key competence factors needed in a Blue Ocean Strategy in terms of product, service and/or delivery. 
We applied this strategy to the fruit Anacardium Occidentale.

While the combination of Six Sigma and Blue Ocean Strategy has been studied before (Meyer 2010), no studies to our knowledge are published where Competitive Technical Intelligence and Blue Ocean is integrated to evaluate agricultural products. Chan and Mauborgne (2005) propose several analytical tools to

Mexican agriculture represents $4 \%$ of the country's GDP; only $11 \%$ of Mexican territory is arable and the agriculture is concentrated in products, such as corn and beans (U.S. Department of State 2010). Unfortunately, the agricultural development has suffered important constraints in the last years; this is the case for Veracruz; a state located in the southern part of the country with an area of $71.820 \mathrm{~km}^{2}$. Veracruz borders with the Gulf of Mexico and has an extended coastline of $745 \mathrm{~km}$. Mexico, particularly in the southern area, has appropriate conditions for the production and marketing of many different agricultural products with high level standards. Some barriers, however, exist. While Veracruz shares are help in this effort: a Six-way Scheme, a Strategic Profile and a Four Action Scheme. The combination of these tools could balance the risk factors in the formulation and execution of the strategy for the final concept implementation. For the purpose of this article, the last two tools are applied.

\section{The Case study}

$4.8 \%$ of all domestic agricultural market, ranking sixth at national level in the category (INEGI2011). The state has hardly increased its area harvested (INEGI 2009), but have very attractive conditions for farmers, including large land area, excellent location, agro-climatic diversity and wide availability of natural resources, especially water. For many years, food production based on short crops periods have been of particular significance for companies in the area (SEDARP 2010).

Veracruz has a large territory which is divided into 212 cities, grouped in 10 administrative areas, as can be seen in Figure 1.

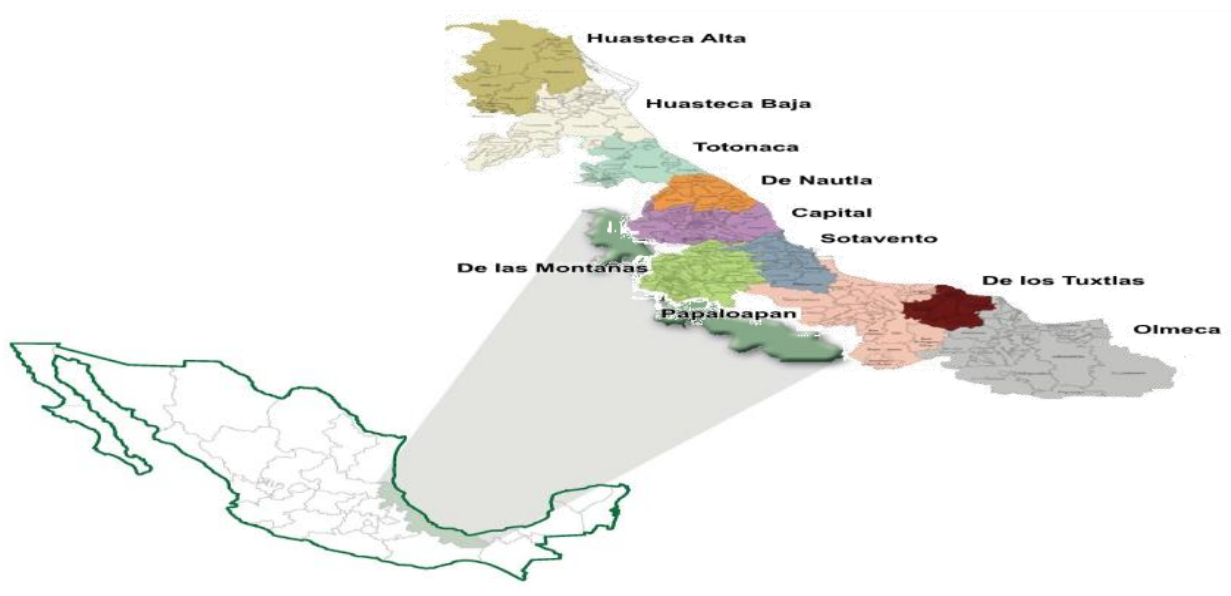

Figure 1: Administrative areas that integrate Veracruz State (Source: INEGI 2010)

We will focus our attention on the district with the highest food production potential: the Olmeca region, which is located in southern Veracruz. This zone has an area of 17,863 $\mathrm{km}^{2}$ and is composed of more than 20 municipalities, as shown in Figure 2. 

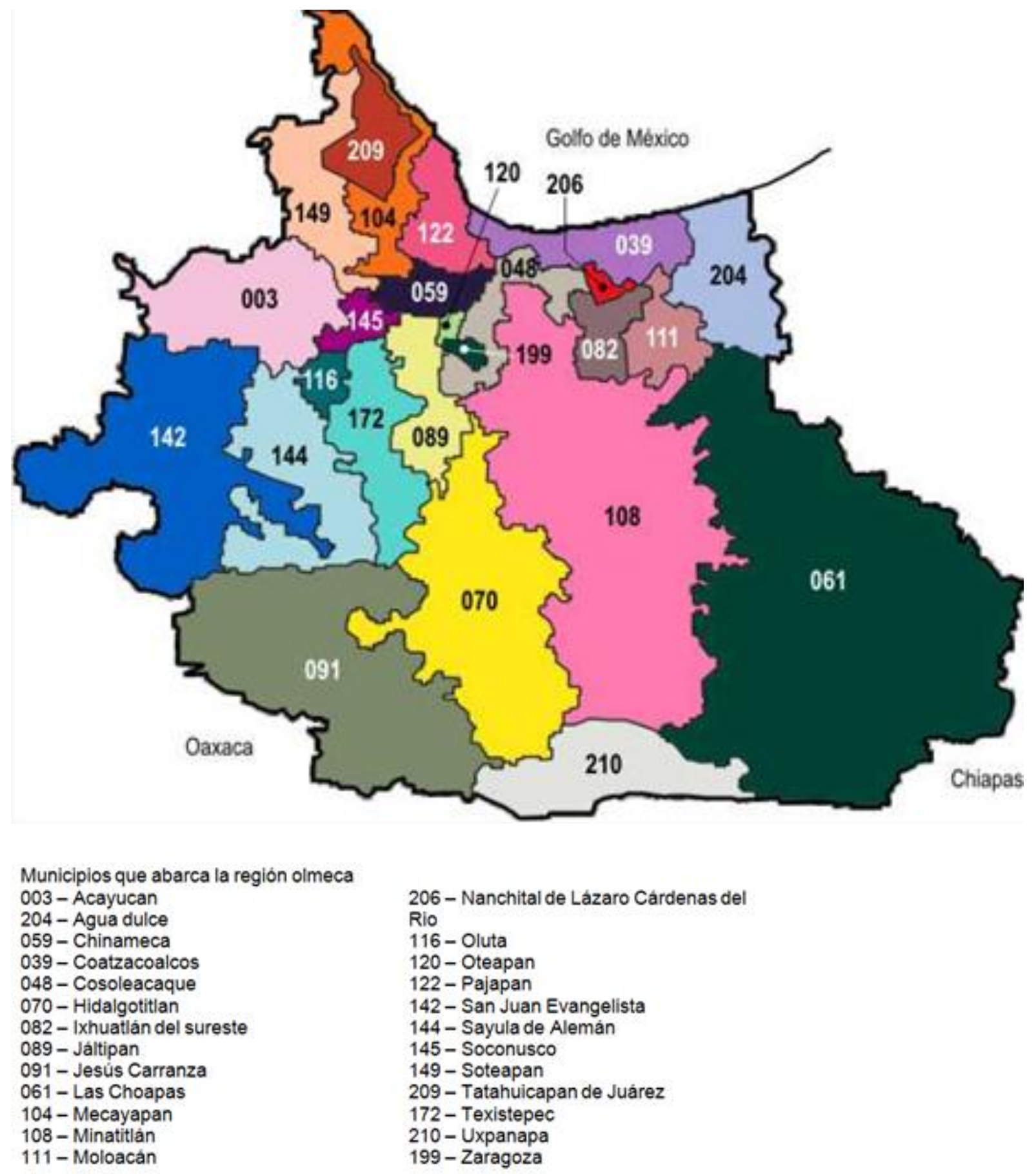

Figure 2: Olmeca Zone (Source: INEGI 2010)

Even though it is one of the most attractive regions, this advantage has not been sufficiently capitalized upon. In most cases, farmers compete with traditional products (where markets are nearly saturated and the return on investment is poor) and they do not normally look for other options. The recommendation is that farmers should focus their efforts on searching for high value alternatives, for example by exploring non-traditional crops or exotic species that would give them a unique differentiation (CONAGUA 2005). In this respect, we apply Competitive Technical Intelligence as a method to explore new opportunities combined with Blue Ocean Strategy. 


\section{Integration Approach}

Based on the Competitive Technical Intelligence methodology proposed by Escorsa y Rodríguez
$(1997,835)$ and the Blue Ocean Strategy of Chan and Mauborgne (2004), a synergic model was designed, as shown in Figure 3.

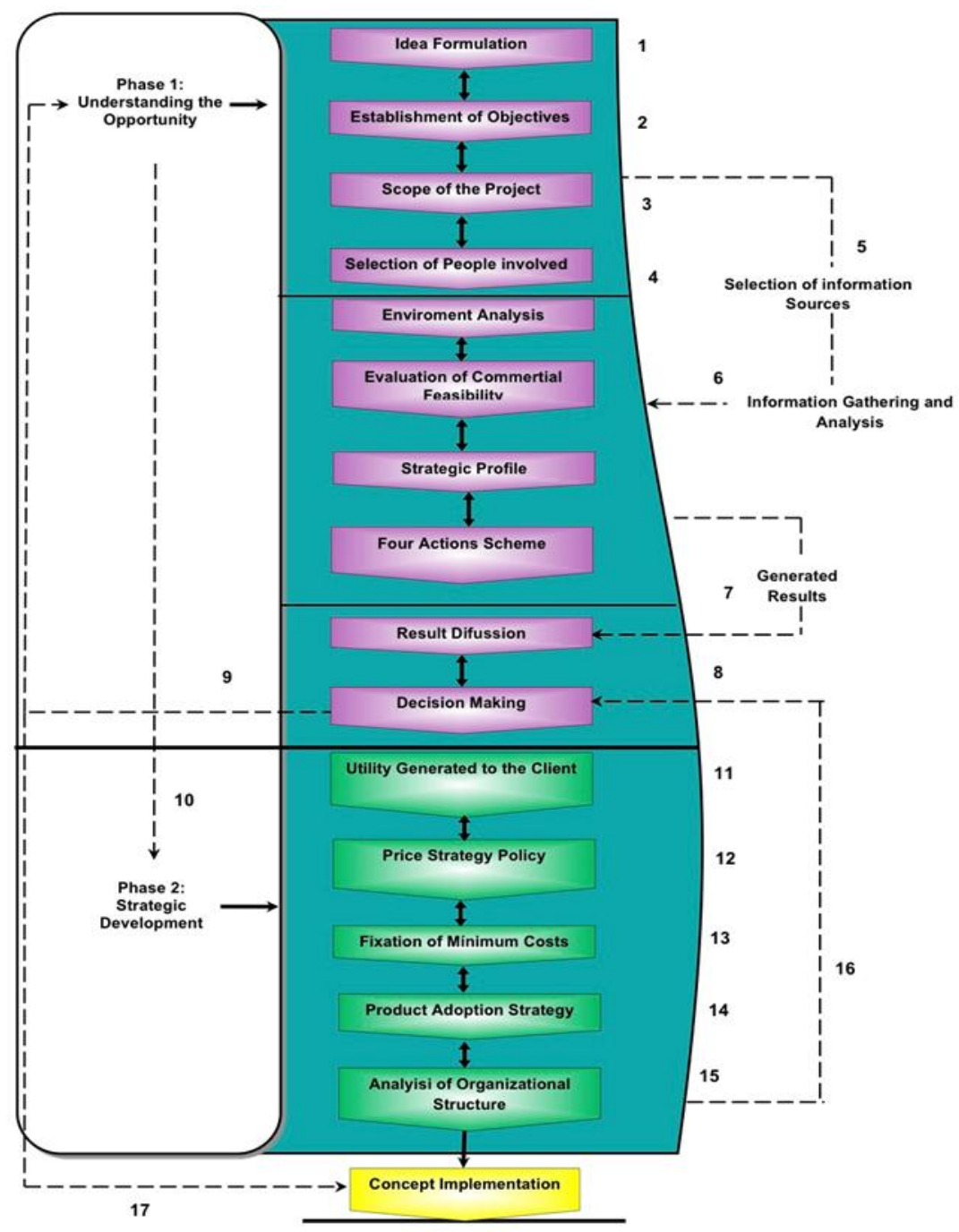

Figure 3: Model of Competitive Technical Intelligence with Blue Ocean Strategy

The objective was to identify and analyze business opportunities in markets that have not been previously explored, such as the case of exotic fruit in our example.

This model is based on cyclic interactions through a process divided in two stages: 1) Understanding opportunities and 2) Strategic development. In the subsequent paragraphs, we present a brief explanation of the development of each stage, including insights obtained from the implementation of the methodology proposed in the model above.

\section{The Methodology}

Even though the model includes both Understanding the opportunity and Strategic Development, for the purpose of this study, we decided of practical reasons to develop only the first part. With this perspective, we hope to show those interested (individuals, companies, associations) new ways to discover business opportunities applying innovative methodologies. The second phase was not developed due to time and space restrictions; it would have been necessary to select a company, establishing utility, 
price, implementation cost and strategy. It will instead be suggested for future research.

\section{$5.1 \quad$ Understanding the Opportunity}

In this phase, the bases of the innovation project is established by employing four activities, starting with idea formulation and establishment of objectives.
According to Otto and Wood (2001, 83-110) the idea of how to drive the project forward should be clearly defined; this includes development of vision and market analysis, including detection of hidden client needs. In our case the project involved the exploration of a non-traditional crop: the Anacardium Occidentale fruit, shown in Figure 4.
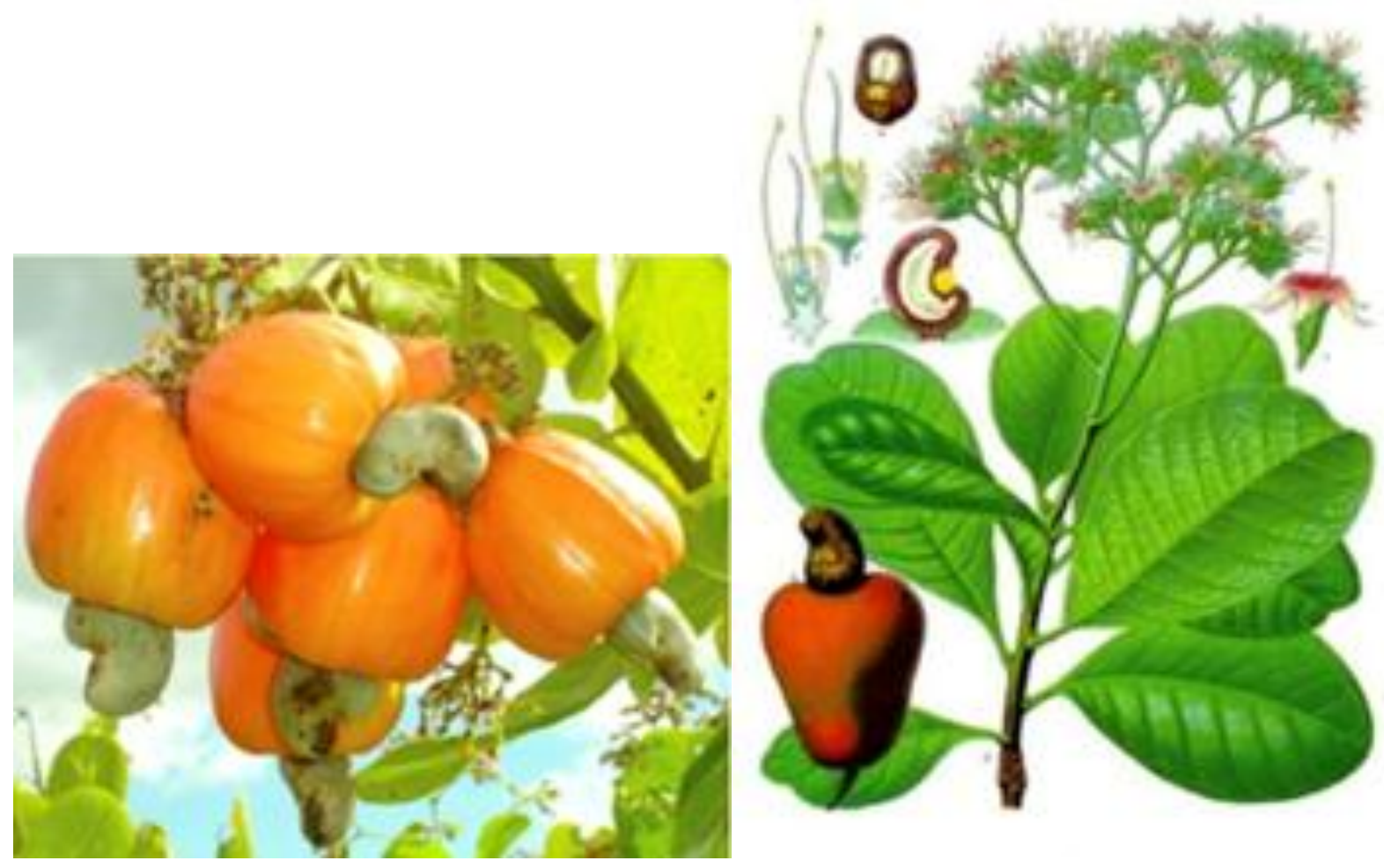

Figure 4: Anacardium Occidentale

Next, Competitive and Technical Intelligence was applied to perform the environment analysis.

Concerning the project, a thorough review of primary and secondary information was completed over a period of six months. Information sources were selected based on content, actuality, legality, and cost efficiency. Access to the digital library resources of ITESM Campus Monterrey was crucial. A primary research was conducted in Veracruz. For this purpose, one municipality of the Olmeca Region was selected (name is confidential). This municipality had more opportunities to grow and develop new business. 10 of the most important farmers of the region were interviewed in terms of their possible interest in the project as well as availability of resources (economic, facilities and basic capabilities needed).
Once the information was gathered, the processing and analysis could start. It is important to emphasize that these activities should focus on getting an actionable final result, which signifies an added value for the decision-making process. In this respect, analysis of the factors that could determine the exit potential of the product (in our case, efficiency in yields and market attractiveness) was the main focus of attention. The analysis indicated that Anacardium Occidentale is appropriate for exploitation. Its crop yields are attractive; for example, in favorable conditions it is possible to harvest approximately 1.4 ton/ha starting from the second year sown. The analysis determined that up to 28 ton/ha of production could be obtained after the 5 th year sown. Concerning the other key factor, the product has a high market value; its commercial value could reach $\$ 221,760$ MXP or 16,234 USD (Bank of Mexico, 
2011) per hectare with a cost to the producer of $\$ 7,920$ MXP or 580 USD per ton.

Continuing with the methodology proposed, an initial Analysis of Commercial Feasibility was performed; possible success or failure of the project determined considering potential attributes for market commercialization. The results of this task helped to create a better strategy for the subsequent correct conceptualization of the product in the market. We also found that the product has a high attractive potential in terms of yield production, price per Ton, and commercial value, in relation to other existing crops in Veracruz (Figure 5).

It is also possible to commercialize different products from it. Cashew nut is the main product of Anacardium, which is widely consumed as a snack and for the elaboration of pastries. Fresh and dried nuts total an annual worldwide demand of about 750,000 ton. Unfortunately, there are no regional statistics on demand in Mexico. There are no statistics concerning exploitation of the other parts of the plant either. This is one of the barriers that the project had to face: the scarcity of detailed information about the fruit. However, after a primary investigation with food engineers, biochemical engineers, farmers, companies and potential clients, we found interesting insights concerning the potential diversity of the plant. Leaves and flowers can be used for the elaboration of teas and essential oils; seeds for the elaboration of stabilizers, margarines, condiments and ingredients for health treatments (mainly ulcers and scars). The fruit peel can be an ingredient in salads, juices, candies, cosmetic products and treatments for respiratory and gastrointestinal diseases.

\begin{tabular}{|c|c|c|c|}
\hline \multicolumn{4}{|c|}{ Comparative Economic Evaluation } \\
\hline Crop & $\begin{array}{l}\text { Yield } \\
\text { (Ton/ } \\
\text { Ha) }\end{array}$ & $\begin{array}{l}\text { Price per Ton } \\
\text { (USD) }\end{array}$ & $\begin{array}{l}\text { Commercial } \\
\text { Value }(\$ U S D / H a)\end{array}$ \\
\hline Papaya & 39.28 & 204.00 & $8,009.00$ \\
\hline Orange & 12.82 & 140.00 & $1,791.00$ \\
\hline Sugarcane & 65.27 & 21.00 & $1,392.00$ \\
\hline Corn & 2.15 & 176.00 & 379.00 \\
\hline $\begin{array}{l}\text { Anacardium } \\
\text { occidentale }\end{array}$ & 28 & 580.00 & $16,234.00$ \\
\hline Maracuyá & 8.16 & 588.00 & $4,779.00$ \\
\hline Pitahaya & 5.28 & 398.00 & $2,094.00$ \\
\hline $\begin{array}{l}\text { Dominical } \\
\text { Banana }\end{array}$ & 15.3 & 132.00 & $2,016.00$ \\
\hline Guanábana & 7.46 & 212.00 & $1,573.00$ \\
\hline Vanilla & 2.5 & $1,533.00$ & $3,816.00$ \\
\hline $\begin{array}{l}\text { Robusta } \\
\text { Coffee }\end{array}$ & 1.68 & $2,647.00$ & $4,427.50$ \\
\hline Pepper & 3.08 & 391.00 & $1,200.00$ \\
\hline Macadamia & 3.88 & 682.00 & $2,646.00$ \\
\hline Ginger & 13 & 147.00 & 1903.00 \\
\hline Anthurium & 6.67 & 159.00 & $1,055.00$ \\
\hline Palm Oil & 20 & 53.00 & $1,054.00$ \\
\hline
\end{tabular}

Figure 5: Comparative Economic Evaluation According to Bank of Mexico September 2011

The subsequent stage of the proposed approach concerns the Strategic profile. This task creates a frame of reference where the key attributes of the project can be identified as the basis that the company will use to define the next competitive strategies. For this, critical factors for success need to be determined considering competitors, performance and events in the environment. Regarding the project, this stage was conducted to identify the variables relative to the crops conditions and performance in terms of production, capacity of industrial diversification, total estimated market value and 
potential net benefit. This information provided a clearer visualization of the critical success factors that would distinguish Anacardium Occidental from the rest of the crops in Veracruz. Due to the strategic value of this information, it is not possible to reveal all insights obtained here, but we can show some details in the next step, The Four Actions Scheme (Figure 6). This activity defines the factors that should be created, increased, reduced or eliminated in order to gain competitiveness.

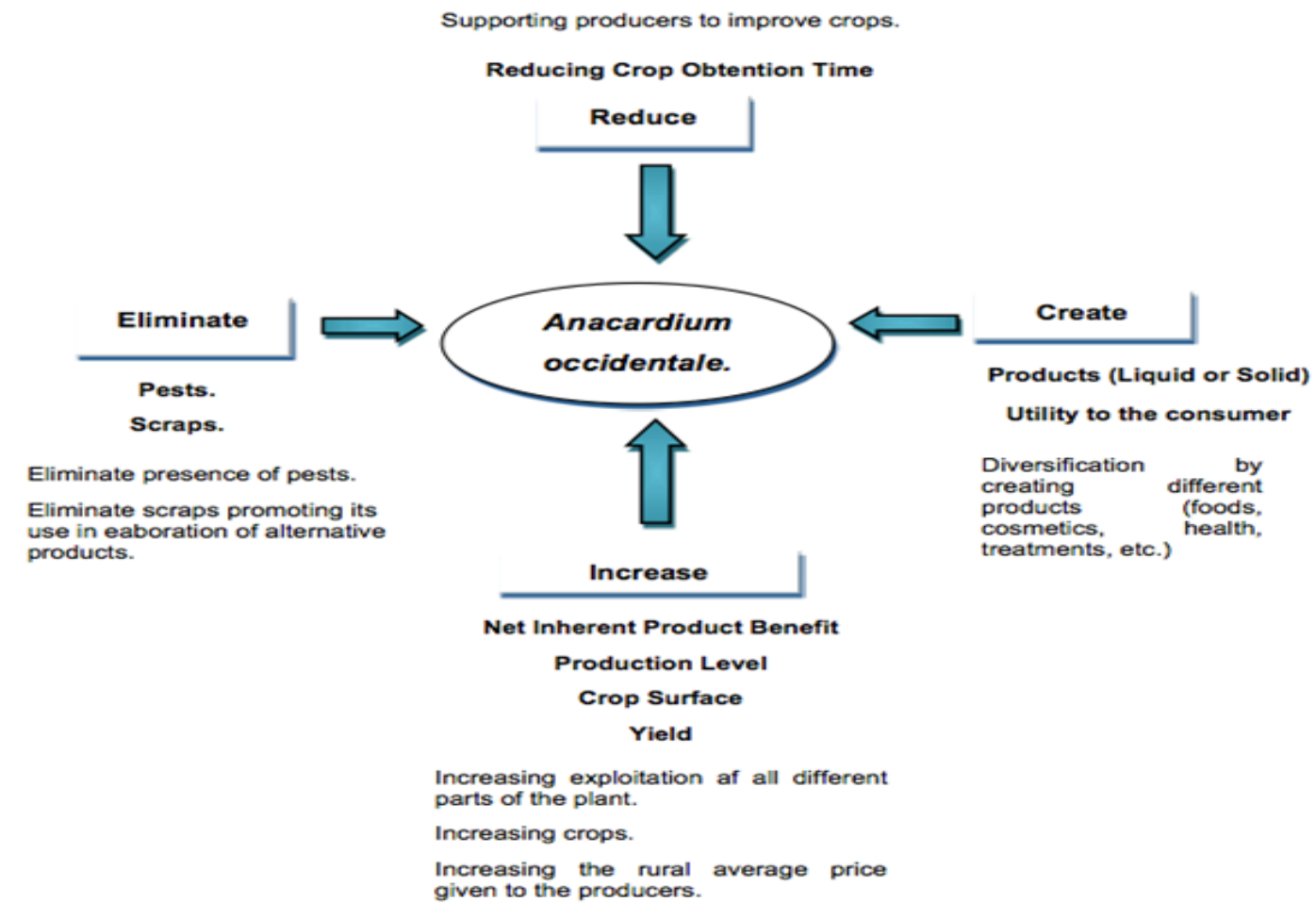

Figure 6: Four Actions Scheme

As shown in Figure 6, the following actions were determined for the project: 1) reducing time of crops, 2) creating different products (food, cosmetics and health treatment), 3) increasing net benefit to consumer as well as increasing crop production, and 4) eliminating pests and scraps. As we have mentioned before, the most important attribute of the plant is its diversification capacity to develop into different natural products. In order to follow the Four Actions Scheme, several elements are necessary, for example: farmers should have specialized technical assistance, access to economic resources and equipment needed to manufacture different kinds of products. The analysis showed that production could start with small quantities, with a small investment and a better distribution of the resources that are already accessible to farmers. We saw that sometimes resources are focused on traditional crops, where utilities are minimal.
While as information was validated and checked for accuracy in previous stages, it is important to make an extra revision before the diffusion of the results, including verification of data interpretation with key people involved in the project. Once final results are determined, they should be disseminated in terms of appropriate content, format and time according to the needs of the client. With reference to this project, results were analyzed by potential investors. As a result, some farmers with a strong interest in the production and commercialization of Anacardium and its products were identified.

Decision Making is the last stage of the first phase: Understanding Opportunities from the methodology. It consists of the final decision by the company of whether to proceed with the next phase of the project or not: Strategic Development.

The methodology is developed in form of a cycle, implying that interactions are important between all 
and for all of the steps. Moreover, the results obtained at the end of the phase Understanding Opportunity can be used for other projects in the identification of other possible opportunities to investigate.

\section{Conclusions}

The model proposed based on the integration of Competitive and Technical intelligence with Blue Ocean Strategy (Figure 3) provides a new perspective for the identification of new businesses to explore. In our case, support from a major academic institution is essential for exploiting new market niches in regions which lack the resources. This is the case of agriculture in the southern region of Veracruz, Mexico. The proposed approach represents an interesting opportunity, since many Mexican companies are preoccupied with their day-to-day competitive problems in already established markets. Awareness concerning the importance of future prevision and management of innovation are areas which are lacking. A common cause of this is insufficient resources (economic, human, methodological, etc.). While companies interested in investing in new approaches, such as the one proposed here, are easier to find in more developed industries, the agricultural sector has traditionally been far behind. However, given the excellent natural resources present in the regions studied, this was an excellent opportunity to consider. From a general point of view, with the application of the proposed methodology, the following benefits were identified:

- Identification of critical factors for success: high diversification capacity, adequate regional weather, extensive crop surface, high yield production and possibility of scraps exploitation

- Identification of opportunities and threats, as well as favorable or unfavorable factors that can significantly affect the business

- Estimation of the feasibility of a business idea taking into account the market potential and the availability of resources.

For future research, the application of the second stage in our plan is recommended: Strategic development, to develop a desirable concept for a particular product, considering aspects such as: uses (in this project, this includes food, cosmetics and medicinal products), performance, presentation, design and production. In order to accomplish this task the following stages should be developed: Determination of the utility generated to the client (for example from the sales process, product delivery, complements offered, etc.), definition of a price strategy policy, fixation of a minimum cost (analysis of alternatives to reduce costs involved in the principal operations of the business), establishment of a Product Adoption Strategy and Analysis of the Organizational Structure. Further stages will define the Concept Implementation activity, which represents the final characteristics definition before launching a new product.

Finally, this project opened for other opportunities to expand activities in the Competitive Technical Intelligence (CTI) domain. When the methodology becomes more available new advantages may emerge in other areas. Companies in development can have access to highly trained personnel from academic institutions. These institutions provide broad information resources and new approaches for uncovering business opportunities. Proof of this was revealed through the Anacardium Occidental project.

\section{References}

Ashton, B., and Klavans, A. 1997. In Keeping Abreast of Science and Technology, Technical Intelligence for Business. Columbus, Ohio: Battelle Press.

Bank of Mexico 2011. Dollar Exchange. Retrieved September 2011. Available online URL: http://www.banxico.org.mx/portal-mercadocambiario/index.html

BOS 2011. About Blue Ocean Strategy. Available online URL: http://www.blueoceanstrategy.com/abo/what_i s_bos.html http://www.scip.org/index.cfm

Chan, W. and Mauborgne, R. 2004a. Blue Ocean Strategy. Part One: Blue Ocean Strategy: 8.

Chan, W. and Mauborgne, R. 2004b. Blue Ocean Strategy. Part Two: Formulating Blue Ocean Strategy, pp. 101-116.

Chan, W. and Mauborgne, R. 2004. Blue Ocean Strategy. Harvard Business Review: pp. 76 84.

Chan, W. and Mauborgne, R. 2005. Blue Ocean Strategy: How to Create Uncontested Market Space And Make the Competition Irrelevant. Massachusetts: Harvard Business Review Press.

CIA 2011. August 24. CIA. Retrieved September 2011. Available online on URL: https:/www.cia.gov/library/publications/theworld-factbook/geos/mx.html

Comai, A. and Tena, J. 2006. Mapping \& Anticipating the Competitive Landscape. Barcelona: Emecom Ediciones, pp. 113-136.

CONAGUA 2005. Veracruz field and agrobusiness. Use of surface and ground water in 
agriculture. Golf Center General Management: Veracruz Mexico. Direct translation from title: El campo y la agroindustria Veracruzana. Aprovechamiento de aguas superficiales y subterráneas en la agricultura. Gerencia Regional Golfo Centro: Veracruz, México, pp. 61-63.

Druehl, C. and Schmidt, G. M. 2008. A Strategy for Opening a New Market and Encroaching on the Lower End of the Existing Market. Production And Operations Management , 17 (1), pp. 44 - 60.

Escorsa, P., and Rodríguez, M. 1997. From information to Technical Intelligence. Direct Translation from: De la información a la Inteligencia Tecnológica. VII Latin American Biannual Seminar of Technology Management: 835.

Grisaleña, D. and Unai, C. 2008 . Competitors Studies: Benefits from analysing competence. Transl. from Estudios de competidores: los beneficios de analizar a la competencia. Puzzle: Spanish CTI Magazine, 6 (29), pp. 26 $-31$.

INEGI 2009. INEGI Mexico in numbers. Retrieved September 2011. Available online on URL:

http://www.inegi.org.mx/sistemas/mexicocifra s/MexicoCifras.aspx?ent=30andmun=0andsec $=\mathrm{G}$

INEGI 2010. INEGI Poblation Report. Retrieved September 2011. Available online on URL: http://www.inegi.org.mx/Sistemas/temasV2/D efault.aspx? s=est \&c=17484

INEGI 2011 INEGI Report 2010. Retrieved September 2011. Available online on URL: http://www.veracruz.gob.mx/wpcontent/uploads/2011/04/perspectiva-ver.pdf

Meyer, J. 2010. In search of blue oceans: The Starwood experience. Available online on URL:
http://knowledge.insead.edu/contents/Starwoo d.cfm

Noriega and Rodríguez. 2011. Evaluation of a Honduran Residential Project with a Competitive Intelligence Proposal Integrating Scenario Analysis and Quality Function Deployment. Competitive Intelligence Magazine, Volume No. 14 Issue No. 2, pp. 3039.

Otto, K. and Wood, K. 2001. Product Design. Techniques in Reverse Engineering and New Product Development. New Jersey: Prentice Hall, pp. 83-110.

Porter A., Roper A., Mason T. and Rossini F. 1991. Forecasting and Management of Technology. New York: J Wiley \& Sons, p. 57.

Price, J. 2000. Competitive intelligence in Latin America: new science meets old practice. Competitive Intelligence Magazine, 4(3) October-December.

SEDARP 2010. Veracruz Agriculture, Livestock, Forestry, Fishery and Food Programs 2005 2010. Retrieved September 2010. Available online on URL: http://portal.veracruz.gob.mx/pls/portal/docs/P AGE/GOBVERSFP/CSFPPTRANSPARENC IA/SFPFRACCIONVIIPVD/SFPPROGRAM ASSECTORIALES/SEDARP.PDF

SCIP 2009. Does CI really make a difference to the bottom line? . Retrevied May 2010. Available on URL: http://www.scip.org/resources/content.cfm?ite mnumber $=601 \&$ navItemNumber $=533$

SCIP 2011. About Strategic and Competitive Intelligence Professionals. Available online on URL: http://www.scip.org/index.cfm

US Department of State 2010. US Department of State December Report. Retrieved September 2011. Available online on URL: http://www.state.gov/r/pa/ei/bgn/35749.htm\#e con 